\title{
Quercus rotundifolia Lam. Woodlands of the Southwestern Iberian Peninsula
}

\author{
Ricardo Quinto Canas ${ }^{1,2, *(\mathbb{D})}$, Ana Cano-Ortiz ${ }^{3}$, Carmelo Maria Musarella ${ }^{4}$, Sara del Río ${ }^{5}$ (D) Mauro Raposo ${ }^{6}$, \\ José Carlos Piñar Fuentes ${ }^{3}(\mathbb{D})$ and Carlos Pinto Gomes ${ }^{6}$ (D)
}

Citation: Quercus rotundifolia Lam. Woodlands of the Southwestern Iberian Peninsula. Land 2021, 10, 268 https://doi.org/10.3390/ land 10030268

Academic Editor:

Guillermo Martinez-Pastur

Received: 10 January 2021

Accepted: 25 February 2021

Published: 6 March 2021

Publisher's Note: MDPI stays neutral with regard to jurisdictional claims in published maps and institutional affiliations.

Copyright: (C) 2021 by the authors Licensee MDPI, Basel, Switzerland. This article is an open access article distributed under the terms and conditions of the Creative Commons Attribution (CC BY) license (https:/ / creativecommons.org/licenses/by/ $4.0 /)$.
1 Faculty of Sciences and Technology, Campus de Gambelas, University of Algarve, 8005-139 Faro, Portugal

2 CCMAR - Centre of Marine Sciences (CCMAR), Campus de Gambelas, University of Algarve, 8005-139 Faro, Portugal

3 Department of Animal and Plant Biology and Ecology, Section of Botany, University of Jaén, Las Lagunillas s/n, 23071 Jaén, Spain; anacanor@hotmail.com (A.C.-O.); jpinar@ujaen.es (J.C.P.F.)

4 Department of AGRARIA, "Mediterranea” University of Reggio Calabria, Località Feo di Vito, 89122 Reggio Calabria, Italy; carmelo.musarella@unirc.it

5 Department of Biodiversity and Environmental Management (Area of Botany), Mountain Livestock Farming Institute (Joint Center CSIC-ULE), Faculty of Biological and Environmental Sciences, Campus of Vegazana, s/n, University of León, E-24071 León, Spain; sriog@unileon.es

6 Department of Landscape, Environment and Planning, Mediterranean Institute for Agriculture, Environment and Development (MED), The Institute for Earth Sciences-ICT, School of Science and Technology, University of Évora, Portugal, Rua Romão Ramalho, n 59, 7000-671 Évora, Portugal; mraposo@uevora.pt (M.R.); cpgomes@uevora.pt (C.P.G.)

* Correspondence: rjcanas@ualg.pt

Abstract: The holm oak woodlands as ecotonic phytocoenoses occur under different ecological conditions, and frequently representing the climax of edaphoxerophilous series of crests and siliceous rocky areas. In this paper we study the floristic, ecological, and biogeographical differences of the edaphoxerophilous holm oak woodlands of the southwestern Iberian Peninsula, included in the Querco rotundifoliae-Oleenion sylvestris suballiance. Our phytosociological (Braun-Blanquet methodology) and numerical analysis (hierarchical cluster analysis) of three formerly described association and our own samples lead us to propose a new association: Ulici argentei-Quercetum rotundifoliae, growing mostly on semihyperoceanic Monchique Sierran Biogeographic District, on rocky slopes and outcrops derived from schists and greywackes. Moreover, we present an overview of ecological features and the diversity of plant communities occurring in the serial dynamic of the thermophile holm oak woodlands of the southwest of the Iberian Peninsula.

Keywords: holm oak woodlands; Quercus rotundifolia; southwestern Iberian peninsula; numerical analysis; vegetation stages; landscape mosaic

\section{Introduction}

The vegetation geoseries or geosigmetum represents the basic unit of dynamic-catenal phytosociology. These correspond to a catena of edaphoxerophilous, climatophilous, climato-temporihygrophilous, and edaphohygrophilous vegetation series, which is found around a given bioclimatic belt and ascribed to an accurate biogeographical territory [1]. The corresponding topographic geosigmetum, which express the universal crest-slopepiedmont-valley model, comprise the vegetation series or sigmeta (sigmetum) zonation along specific ecological features, resulting from geomorphic systems that interact over time to shape the topography of the landscape unit.

According to Rivas-Martínez et al. [2] and Loidi [3], the climatophilous or zonal series occupy large areas of land (normally, are found in hillslopes) and are located on mature soils according to the mesoclimate, i.e., are conditioned by non-exceptional conditions; the temporihygrophilous series, included among the climatophilous, are those which have 
additional water contribution due to slope runoff (piedmont), nevertheless during the summer or dry period the soil horizons are well-drained and aerated; the hygrophilous series grow on particularly wet soils and biotopes linked to river beds, marsh areas, salt flats, peat bogs, or any places which are wet due to the gravitational input of water. Finally, the xerophilous series can be found in the driest sites (crests, rocky slopes, lithosols, leptosols, and arenosols). In this context, the holm oak (Quercus rotundifolia) communities of the southwestern Iberian Peninsula are of particular interest. Frequently, they develop in edaphoxerophilous biotopes that appear as evidence of extreme xericity conditions, namely great edaphic draught as a result of the soils reduced capacity for water retention $[4,5]$. In these situations, which are often associated to crests and rocky areas, the edaphoxerophilous holm oak woodlands are characterized by xerophytic floristic patterns, in comparison with the encompassing potential natural vegetation.

The holm oak vegetation series dominate large areas of Iberian Peninsula, since Quercus rotundifolia plant communities are present in a wide range of bioclimatic stages (ranging from dry to humid ombroclimates in the thermomediterranean to supramediterranean belts) and pedological/lithological substrata (e.g., schist, greywacke, quartzite, limestone, calco-dolomitic), and tends to occupy environments with special characteristics, especially when compared with the other native forest species. Among the wide spectrum of sites and special environments, the widespread of Quercus rotundifolia has been also favoured by human activities, as a direct result of long-lasting impact of human agroforestry and grazing land-use practices.

The present paper aims to provide a new knowledge of the thermophilous holm oak communities of the southwestern Iberian Peninsula (Figure 1), included in the Querco rotundifoliae-Oleenion sylvestris suballiance. The phytosociological and syntaxonomical vegetation analysis allow us to distinguish a new forest Ulici argentei-Quercetum rotundifoliae. In addition, we present an overview of ecologic factors and processes controlling the diversity of plant communities observed in their dynamic - as well as the characteristic vascular flora-which dominate large areas of holm oak forest landscape.

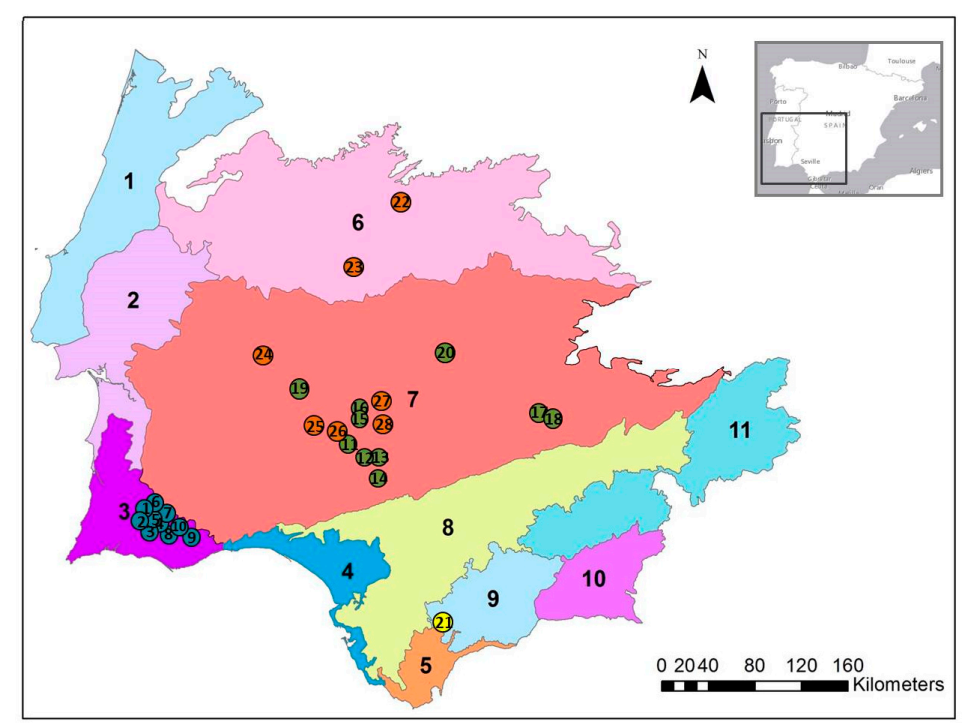

Figure 1. Biogeographic map of the southwest of the Iberian Peninsula at sector level, following [2] (1-Divisorio-Portuguese Sector; 2-Ribatejo and Sado Sector; 3-Algarve and Monchique Sector; 4Cádiz and Littoral Huelva Sector; 5-Algeciras and Aljibe Sector; 6-Oretana Range and Tajo Sector; 7-Mariánica Range Sector; 8-Campiña of Guadalquivir Sector; 9-Ronda Sector; 10—Granada and Almijara Sector; 11-Subbética Sector). Numbers of dots correspond to those of Table A1 and Figure 2. 


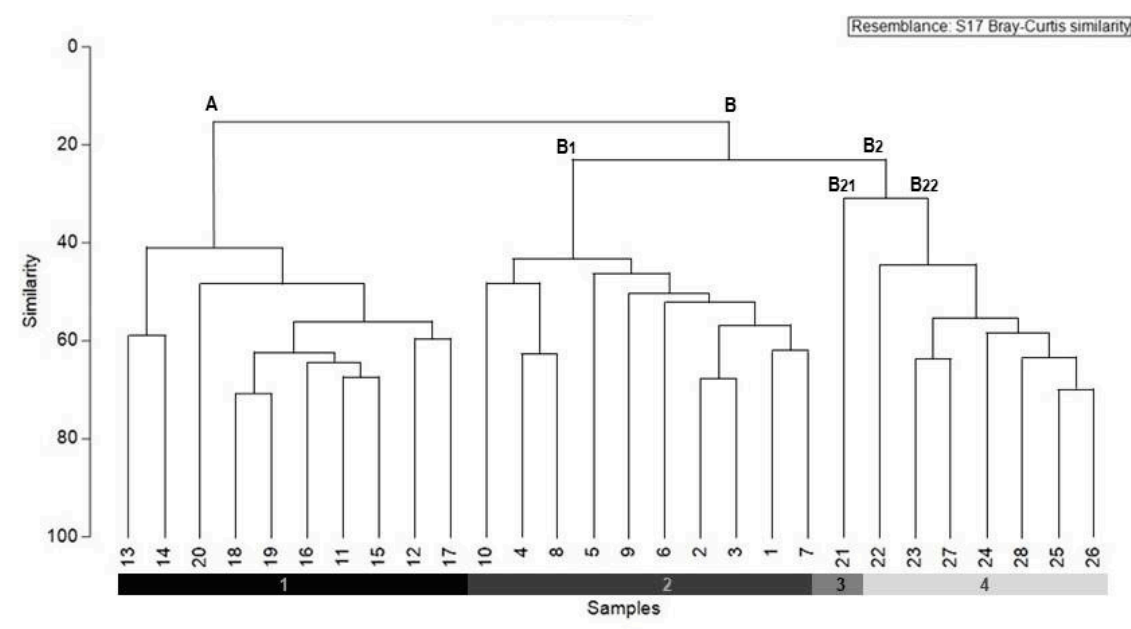

Figure 2. Classification analysis (UPGMA clustering dendrogram, with Bray-Curtis distance): Group A includes 1-Myrto communis-Quercetum rotundifoliae (11-20); Group B includes 2-Ulici argenteiQuercetum rotundifoliae (B1; 1-10), 3-Rhamno oleoidis-Quercetum rotundifoliae (B21; 21) and 4-Rhamno laderoi-Quercetum rotundifoliae (B22; 22-28).

\section{Materials and Methods}

\section{Data Collection}

Field sampling was carried out from March 2013 to April 2014, following the ZurichMontpellier phytosociological method [6-9]. Here, we defined a new woodland association, based on the comparison of phytosociological relevés, performed in Table A1. According to Biondi [9], each relevé is a floristically and ecologically homogeneous plant community that represents the plant association on the ground. Within this definition, for each relevé, all plants that are found in an area whose floristic, structural, and ecological conditions are homogenous, were identified and assigned a quantitative value or index for their coverage, using the conventional abundance-dominance scale of Braun-Blanquet [10].

Nomenclatures used

Syntaxonomical typologies were checked according to Rivas-Martínez et al. [11-13] Costa et al. [14] and Mucina et al. [15] while for flora identification, the following works have been used: Coutinho [16], Franco [17], Franco and Rocha Afonso [18], Castroviejo [19], and Valdés et al. [20]. Botanic nomenclature were update using former Iberian lists elaborated by Rivas-Martínez et al. [12], Sequeira et al. [21] and Costa et al. [14]. For biogeographical and bioclimatological information we follow Rivas-Martínez et al. [1,2,22] and substratum affinity information were taken from the literature: Rivas Goday et al. [23], Rivas-Martínez et al. [12,13], and Quinto-Canas [24], as evidence in Appendix A, Table A2. The phytosociological name of the new vegetation unit is given according to the International Code of Phytosociological Nomenclature [25].

\section{Data analysis}

The data matrix, consisted of 28 relevés and 212 taxa, was submitted to the Un-Weighted Pair-Group Method using Arithmetic Averages (UPGMA), with Bray-Curtis distance, to produce the dissimilarity measure, using the software Primer 6 [26,27]. The Braun-Blanquet's abundance-dominance indexes were transformed according to Van der Maarel [28]. This transformation is required, as a solution for converting the non-numerical values into numerical scale and in this form used as input data for numerical analysis. The relevés performed in data matrix include our field sampling (Appendix A, Table A3; Table A1, association 1; clusters 1-10) and relevés taken from the literature: Rivas Goday et al. [23] (Appendix A, Table A1, association 2; clusters 11-20), Rivas-Martínez et al. [12] (Appendix A, Table A1, association 3; cluster 21) and Rivas-Martínez et al. [13] (Appendix A, Table A1, association 4; clusters 22-28). 


\section{Results and Discussion}

\subsection{Classification of Southwestern Iberian Peninsula Holm Oak Communities}

The dendogram and synoptic table reveal a clear separation between all phytosociological holm oak communities of the Southwestern Iberian Peninsula, included in the Querco rotundifoliae-Oleenion sylvestris suballiance. Indeed, as showed in Figure 1, four different groups can be detected, based on floristic similarities (Appendix A, Table A1), responding to different ecological gradients (Appendix A, Table A2) and representing the following syntaxonomical units (associations): (A) Myrto communis-Quercetum rotundifoliae (clusters 11-20); (B1) Ulici argentei-Quercetum rotundifoliae (clusters 1-10); (B21) Rhamno oleoidis-Quercetum rotundifoliae (clusters 21); (B22) Rhamno laderoi-Quercetum rotundifoliae (cluster 22-28). Group A, encompasses samples contained the silicicolous association Myrto communis-Quercetum rotundifoliae, which mainly occurs in the dry to subhumid thermomediterranean bioclimatic areas of the Southern Iberian biogeographic territory. Group B comprises two subgroups. The first disjoin is subgroup B1, which encompasses the relevés contained in the association Ulici argentei-Quercetum rotundifoliae, which is proposed here as new association, largely confined to the siliceous mountains of southwest of Portugal (Monchique Sierran District). The subgroup B2, comprises two different basophilous associations: Rhamno laderoi-Quercetum rotundifoliae (B22) and Rhamno oleoidis-Quercetum rotundifoliae (B21). The first, which can be found on limestone, calco-dolomitic and ultramafic (serpentine) substrates of the Lusitania and Extremadura Subprovince, is highlighted by the presence of Rhamnus laderoi, whereas the latter occurs on limestone and calco-dolomitic substrates of the Bética Province, reaching the southernmost coastal or sub-coastal areas of Portugal (Algarve and Monchique Sector, Cádiz and Sado Subprovince).

The Table A1 (Appendix A) reveals the differences in floristic composition among these four groups defined in the dendrogram, based on the presence/absence of diagnostic species as a response to different bioclimatic stages, edaphic conditions, and biogeographic distributions (Appendix A, Table A2; Figure 2). The Quercus rotundifolia woodlands of the Southwestern Iberian Peninsula (in the Querco rotundifoliae-Oleenion sylvestris suballiance) are briefly described below, from a floristic, ecological, and dynamic point of view.

\subsection{Description of Holm Oak Communities}

I-Ulici argentei-Quercetum rotundifoliae ass. nova hoc loco (Appendix A, Table A3; clusters 1-10)

The relevés of the new association Ulici argentei-Quercetum rotundifoliae (holotypus Appendix A, Table A3, relevé 7) have a high dissimilarity in relation to the other associations. These holm oak woodlands are exclusive to the southern territories of the Monchique Sierran District, particularly in the sub-coastal siliceous areas of the Caldeirão Mountains [24]. They form edaphoxerophilous micro-forests on incipient lithosols, rocky slopes and outcrops derived from schists and greywackes, and are found in the thermomediterranean sub-humid belt, where it appears to have its optimum.

Of particular interest is the frequent presence of Ulex argenteus, an acidic gorse, exclusively found in the oceanic biogeographic areas of the Algarve and Monchique Sector. Of the various species represented here, we also highlight the presence of other oceanic species, such as: Scilla monophyllos, Avenella stricta, Lavandula viridis, Osyris lanceolata, Cynara algarbiensis. As shown in Table A3 (Appendix A), the floristic composition of these woods also contains other characteristic species from the Quercetea ilicis species, like Erica arborea, Quercus coccifera, Pistacia lentiscus, Arbutus unedo, all occur frequently and Rhamnus alaternus, Phillyrea angustifolia, Olea europaea var. sylvestris, more occasionally. The canopy is further enriched by Smilax aspera var. altissima, Lonicera implexa, Rubia peregrina. Regarding the xerophilous position, the flora of the Ulici argentei-Quercetum rotundifoliae is characteristic with its much more obvious rupicolous elements: Umbilicus rupestris, Phagnalon saxatile, Rumex induratus, Saxifraga granulata, Cheilanthes guanchica, Sanguisorba rupicola, among others. The degradation of the Ulici argentei-Quercetum rotundifoliae woodland lead us to the formations dominated by Quercus coccifera, enriched by nanophanerophytes from Ericion 
arboreae (Rivas-Mart. ex Rivas-Mart. et al. 1986) Rivas-Mart. 1987 (Erica arborea and Arbutus unedo) and Calluno -Ulicetea Br.-Bl. Et Tx. Ex Klika et Hadac (Erica australis, Genista triacanthos, Calluna vulgaris). Nevertheless, cutting and burning have almost certainly reduced the extent of these communities, favoring the occurrence of the heathland characterized by Erica australis and Ulex argenteus and the broomland dominated by Genista polyanthos (Genistetum triachanthi-polyanthi Vila-Viçosa, Mendes, Meireles, Quinto-Canas \& Pinto-Gomes 2013). Elsewhere, though, all these communities persist as a fragment in their occurrence as landscape mosaic, now largely converted to gorse scrubland dominated by Cistus ladanifer and Ulex argenteus (Cisto ladaniferi-Ulicetum argentei Br.-Bl., P. Silva \& Rozeira 1964), whereas in its clearings occurs the pioneer communities dominated by the non-nitrophilous therophytes such as Plantago bellardii (Trifolio cherleri-Plantaginetum bellardii Rivas Goday 1958) and Brachypodium distachyon (Holco annui-Brachypodietum distachyi S. Ribeiro, Ladero \& Espírito Santo 2012). Moreover, inhabiting narrow rocky fissures, we must highlight the presence of the chasmophytic community dominated by Cheilanthes guanchica.

We place the Ulici argentei-Quercetum rotundifoliae ass. nova hoc loco, at the syntaxonomic level, in the Querco rotundifoliae-Oleenion sylvestris suballiance (Oleo sylvestrisQuercion rotundifoliae, Quercetalia ilicis, Quercetea ilicis).

II-Myrto communis-Quercetum rotundifoliae Rivas Goday in Rivas Goday, Borja, Esteve, Galiano, Rigual \& Rivas-Martínez 1959 (clusters 11-20, Figure 2)

This holm oak association occurs through the southern and southwestern part of the Iberian Peninsula, where represents the climax vegetation over siliceous substrates. Despite the wide distribution, it is in the thermomediterranean sites with dry ombrotype of the Mediterranean-Iberoatlantic biogeographic territories that this community constitutes the mature climatic stage, and therefore is not present in Monchique Sierran District, where it is substituted by the association Ulici argentei-Quercetum rotundifoliae. As evidenced by RivasMartínez et al. [13], the characteristic species of the Myrto communis-Quercetum rotundifoliae are Quercus rotundifolia, Myrtus communis, Chamaerops humilis and Lavandula sampaioana. According to the original description of Rivas Goday in [23], its floristic composition is very rich and characterized by an abundant presence of species of the order Pistacio lentisci-Rhamnetalia alaterni Rivas-Mart. 1975: Pistacia lentiscus, Rhamnus alaternus, Rhamnus oleoides, Osyris alba, Jasminum fruticans, Pistacia terebinthus, among others. On this basis, as first substitution stage, the silicicolous variant of the Asparago albi-Rhamnetum oleoidis Rivas Goday 1959 maquis emerges, where Pistacia lentiscus, Olea europaea var. sylvestris, Rhamnus oleoides, Asparagus albus, Osyris lanceolata dominate. Meanwhile, most of forest and pre-forest have been strongly influenced by human activity, which favoured the occurrence of seral scrub communities: Genisto hirsutae-Cistetum ladaniferi Rivas Goday 1955 and Genistetum polyanthi Rivas-Martínez \& Belmonte ex Capelo, Lousã \& J.C. Costa 1996. The first, correspond to the association co-dominated by Cistus ladanifer, Lavandula luisieri and Genista hirsuta. The second association corresponds to the broomland almost constituted by Genista polyanthos. Additoinally, typical in xerophilous positions, at lower level or open stands of the scrubs, are the Dauco criniti-Hyparrhenietum sinaicae Rivas-Martínez in RivasMartínez, Fernández-González \& Sánchez-Mata 1986 corr. Díez Garretas \& Asensi 1999 perennial grasslands, dominated by Hypharremia sinaica accompanied by Daucus crinitus, Daucus setifolius, Dipcadi serotinum, Andryala integrifolia, among others.

Furthermore, at later stage in succession, zonation involves the annual grasslands of Trifolio cherleri-Plantaginetum bellardii, usually dominated by therophitic species, such as Plantago bellardii, Trifolium cherleri, Aira cupaniana, Tolpis barbata, Hymenocarpos lotoides, Leontodon taraxacoides subsp. longirostris, among others. In areas subject to moderate disturbance, often grazing-related, this community is replaced by the subnitrophilous grasslands, represented by the Trifolio cherleri-Taeniatheretum capitis-medusae Rivas-Martínez \& Izco 1977 association, in which Taeniatherum caput-medusae, Trifolium cherleri, Stipa capensis, occurs. But the cumulative effect of trampling by regulated and persistent grazing, mainly sheep, promotes the occurrence of perennial grasslands included in the Trifolio subterraneiPoetum bulbosae Rivas-Martínez \& Izco 1977 association (Poetea bulbosae Rivas Goday et 
Rivas-Mart. in Rivas-Mart. 1978 vegetation class), dominated by the hemicryptophyte Poa bulbosa, usually accompanied by other characteristic species of the Poetea bulbosae class, such as Trifolium subterraneum, Trifolium bocconei, Trifolium gemellum, Trifolium glomeratum, Biserrula pelecinus, Bellis annua, Erodium botrys, Erodium brachycarpum, Lupinus micranthus, among others [24]. This perennial grassland presents a high-value to livestock grazing and appears as part of managed, cultural silvopastoral or agro-silvopastoral systems known as montados in Portugal and dehesas in Spain. Furthermore, the intensive overgrazing increases in the abundance of nitrophilous species from Artemisietea vulgaris Lohmeyer et al. in Tx. ex von Rochow 1951 vegetation class. According to Quinto-Canas et al. [29], on soils with poor drainage, with slight flooding length, occurs hygrophilous grasslands with a frequent presence of characteristic species from the Stipo giganteae-Agrostietea castellanae Rivas-Mart. et al. 1999 class (such as, Agrostis castellana, Gaudinia fragilis, Linum bienne, Rumex acetosella subsp. angiocarpus) or from the Isoeto-Nanojuncetea Br. Bl. et Tx. in Br.-Bl. et al. 1952 class (Agrostis pourretii, Cicendia filiformis, Isoetes histrix).

When these holm oak woodlands cover edaphoxerophilous positions they typically form mosaics with other vegetation types, included in the class Asplenietea trichomanis (Br.-Bl. in Meier \& Br.-Bl. 1934) Oberdorfer 1977 and Phagnalo saxatilis-Rumicetea indurati Rivas Goday et Esteve 1972) Rivas-Mart. et al. 1973, which comprises plant communities characterized by rupicolous chasmophytic or chasmochomophytic species that grow on rocky crevices. Thus, in fissures of cliffs or rocky outcrops, occur the communities dominated by small ferns, such as Cosentinia vellea (Cheilantho maderensis-Cosentinietum velleae Ladero ex F.J. Pérez, T.E. Díaz, P. Fernández \& Salvo 1989) and Cheilanthes tinaei (Asplenio billotii-Cheilanthetum tinaei Rivas-Martínez \& Costa 1973 corr. Sáenz \& Rivas-Martínez 1979). In the group of the chasmochomophytic vegetation, we must highlight the presence of a community dominated by Dianthus crassipes, usually accompanied by Sanguisorba rupicola, which tend to colonize fissures with slight addition of soil.

III-Rhamno oleoidis-Quercetum rotundifoliae Rivas-Martínez in Rivas-Martínez, Fernández-González, Loidi, Lousã \& Penas 2002 (cluster 21, Figure 2)

The holm oak woodlands of the southwest of the Iberian Peninsula (Bética and Cádiz and Sado biogeographic territories) typically associated to limestone and calco-dolomitic substrates corresponds to the Rhamno oleoidis-Quercetum rotundifoliae. This woodland has its optimum development in the thermomediterranean, dry to subhumid, bioclimatic belt, and can be differentiated by the presence of typical basophilous species, such as Ulex baeticus subsp. scaber, Thymbra capitata, Cistus albidus, Ptilostemon hispanicus. These Quercus rotundifolia woods can develop dense canopy, with a high presence of climbing species, such as Aristolochia baetica, Clematis flammula, Smilax aspera var. altissima, Rubia peregrina, Lonicera implexa. Other thermophile species, occurring throughout the community or more frequently in its preforest community (ascribed to the calcicolous variant of the association Asparago albiRhamnetum oleoidis), including Pistacia lentiscus, Phillyrea latifolia, Olea europaea var. sylvestris, Rhamnus oleoides, Rhamnus alaternus, Chamaerops humilis, Phlomis purpurea, Ceratonia siliqua, Asparagus aphyllus, among others. In open areas of woodlands and their pre-forestry mantles, occur perennial xerophytic grasslands, dominated by Brachypodium phoenicoides, Brachypodium retusum, Stipa tenacissima, Hyparrhenia hirta and Hyparrhenia sinaica.

According to Paiva-Ferreira and Pinto-Gomes [30] and Molero and Marfil [31], the vegetation occurring on more disturbed limestones soils include several gorses and thymes associations, which represent one of the richest complexes types that are found in the scheme of this holm oak woodland, where Ulex baeticus subsp. scaber, Thymbra capitata, Thymus baeticus, Cistus albidus, Genista retamoides, Genista equisetiformis, Genista hirsuta subsp. algarbiensis, Genista haenseleri, Retama sphaerocarpa, Ulex willkommii, Asparagus horridus, Fumana thymifolia, among others.

As evidence by Quinto-Canas et al. [32], the degradation of the shrubby communities by human activities (firewood, ploughing, deforestation) promotes the development of annual grasslands from the pioneer association Velezio rigidae-Asteriscetum aquaticae Rivas Goday 1964, dominated by non-nitrophilous therophytes, such as Asteriscus aquaticus, Cleo- 
nia lusitanica, Velezia rigida, Campanula erinus, among others. In areas subjected to grazing, this pioneer community are replaced by Trifolio subterranei-Plantaginetum serrariae, dominated by graminoids and herbs (Poa bulbosa, Plantago serraria, Erodium primulaceum, Trifolium tomentosum) and geophytes (Gynandriris sisyrinchium, Scilla autumnalis) [26]. Moreover, on cliffs, rock outcrops or rocky soils, the Rhamno oleoidis-Quercetum rotundifoliae woodlands behaves as more open formations and encompasses calcicolous chasmophytic communities, which inhabiting narrow fissures, such as those co-dominated by Narcissus calcicola and Narcissus gaditanus (included in the association Narcisso calcicolae-gaditanae Pinto-Gome, E. Cano, J.A. Torres, Paiva-Ferreira \& Rosa Pinto in Pinto-Gomes \& Paiva-Ferreira 2005), mostly found in sub-coastal areas of southern part of Algarve (Algarve District).

IV-Rhamno laderoi-Quercetum rotundifoliae Rivas-Martínez, M.T. Santos \& Ladero 2011 (clusters 22-28, Figure 2)

For the Lusitania and Extremadura biogeographic territories, Rivas-Martínez et al. [13] published the holm oak forest Rhamno laderoi-Quercetum rotundifoliae, well characterized by the presence of Rhamnus lycioides subsp. laderoi. This association occurs on calcareous, calcodolomitic and ultramafic or serpentine substrates, within upper thermomediterranean or lower mesomediterranean, subhumid, bioclimatic belts. The floristic composition of these woodlands also contains other characteristic species from the Quercetea ilicis vegetation class, such as Olea europaea var. sylvestris, Quercus coccifera, Pistacia lentiscus, Pistacia terebinthus, Jasminum fruticans, Rhamnus oleoides, Teucrium fruticans, which reveals the catenal relationship with the first substitution stage, linked to the association Asparago albi-Rhamnetum oleoidis. As shown in Table A1 (Appendix A), the Quercus rotundifolia wood is also characterized by the presence of climbing shrubs (e.g., Rubia peregrina, Smilax aspera, Lonicera implexa, Lonicera etrusca, Asparagus acutifolius, Asparagus albus), and nemoral herbs and geophytes in the understory, including Thapsia nitida, Elaeoselinum foetidum, Magydaris panacifolia, Paeonia broteri, Ruscus aculeatus. The consistent presence of Cistus albidus in the companion group reveals the contact with the serial regressive community Lavandulo sampaioanae-Cistetum albidi M.T. Santos in Rivas-Martínez, Lousã, T.E. Díaz, Fernández-González \& J.C. Costa 1990, favored by humaninduced disturbance such as periodic soil mobilization. Finally, the land use and disturbance events promote the occurrence of the last subseral stage, linked to the annual grasslands from the Helianthemetea guttati Rivas Goday et Rivas-Mart. 1963 class, which colonize clearings of the scrublands and perennial grasslands.

\subsection{Syntaxonomical Scheme}

QUERCETEA ILICIS Br.-Bl. ex A. \& O. Bolòs 1950

QUERCETALIA ILICIS Br.-Bl. ex Molinier 1934

Oleo sylvestris-Quercion rotundifoliae Barbero, Quézel et Rivas-Mart. in Rivas-Mart. et al. 1986 Querco rotundifoliae-Oleenion sylvestris J.C. Costa, C. Neto, C. Aguiar, J. Capelo, M.D. Espiríto Santo, J. Honrado, C. Pinto-Gomes, T. Monteiro-Henriques, M. Sequeira, M. Lousã 2012

Ulici argentei-Quercetum rotundifoliae Quinto-Canas, Cano-Ortiz, Musarella, del Río, M. Raposo, Piñar Fuentes \& Pinto-Gomes ass. nova

Myrto communis-Quercetum rotundifoliae Rivas Goday in Rivas Goday, Borja, Esteve, Galiano, Rigual \& Rivas-Martínez 1959

Rhamno oleoidis-Quercetum rotundifoliae Rivas-Martínez in Rivas-Martínez, FernándezGonzález, Loidi, Lousã \& Penas 2002

Rhamno laderoi-Quercetum rotundifoliae Rivas-Martínez, M.T. Santos \& Ladero 2011

3.4. Considerations of the Typical Sequence of Vegetation Stages Occurring in the Holm Oak Vegetation Series

The Quercus rotundifolia woodlands constitute unique ecosystems that are recognized for their ecological value, linked to water retention, watershed protection, reducing fire risk and soil erosion, carbon sequestration and key-habitats for rare and endemic species [33]. However, as evidence by Quinto-Canas [24] and Quinto-Canas et al. [32] these oak forests have been transformed throughout history and well-preserved examples are rare, since their 
extension have been considerably reduced in area due to the cumulative effect of various kind anthropic interference, namely cutting, inappropriate silvicultural management, mechanized shrub clearance, intensive grazing, agricultural intensification, and forest fires (Figure 3).

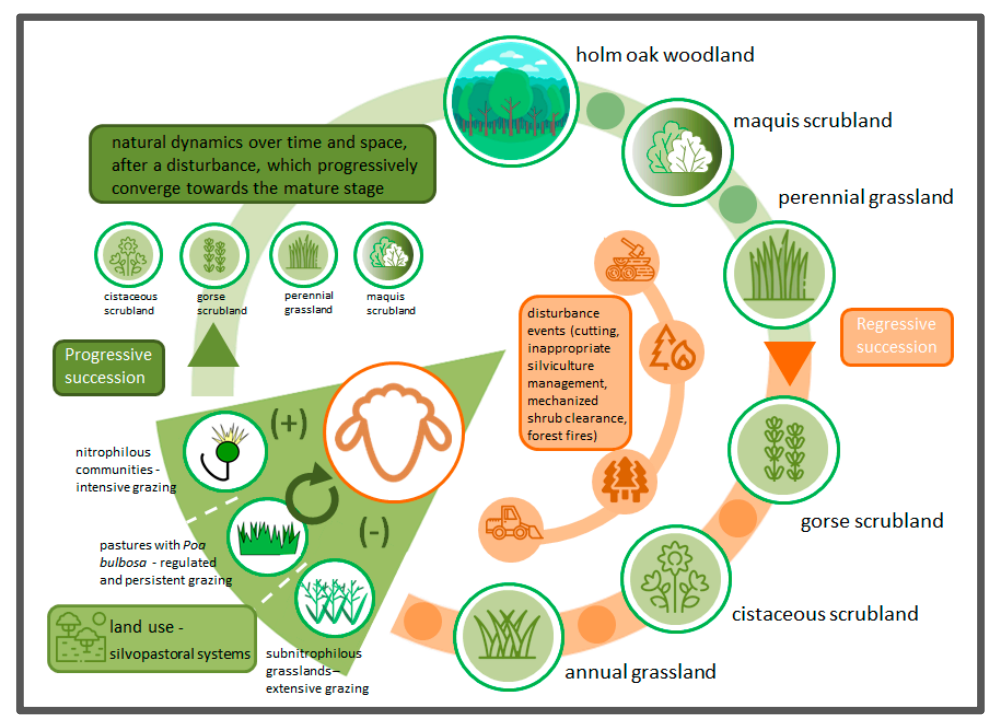

Figure 3. Diagram representing the typical sequence of vegetation stages occurring in the holm oak vegetation series from southwest of Iberian Peninsula.

These practices lead to the degradation of holm oak woodlands and consequently, current vegetation cover (in anthropic modified landscapes) are dominated by lower layers and stages of vegetal dynamics (such as, maquis scrubland, broomland, perennial grassland, gorse and cistaceous scrubland, and annual grasslands) or agricultural and silvopastoral systems.

\section{Conclusions}

As a result of this work we have been able to extend the forest communities dominated by Quercus rotundifolia in the south of Portugal. The new association Uliciargentei-Quercetum rotundifoliae, with an edaphoxerophilous character, has an original floristic patterns and specific ecological features that segregate biogeographically this association from the other holm oak woodlands of Querco rotundifoliae-Oleenion sylvestris suballiance in the southwestern Iberian Peninsula. In order to ensure its preservation, this community should be enacted through the Habitats Directive 92/43/EEC, under the Natura 2000 code: 9340 Quercus ilex and Quercus rotundifolia forests habitat, from the Annex I habitat types of the Council Directive 92/43/EEC of 21 May 1992.

Moreover, the Southwestern Iberian Peninsula holm oak woodlands occur in less accessible areas, mostly restricted to small patches and consequently, conservation measure required to achieve favorable conservation status of Quercus rotundifolia woodlands. Hence, strategic policies recommendations include: (i) Protect the holm oak woodlands through regulation, environmental planning instruments and assessment, in order to avoid its destruction driven by changes in land use (mainly, forestry planting, agricultural, grazing, soil mobilization); (ii) ensure that the protection of rare species is factored into management/monitoring objectives; (iii) increase efficiency of forest monitoring to ensure the long-term future of holm oak woodland habitat area; and (iv) apply environmental and ecological economics tools to the valuation of biodiversity conservation and ecosystem services of holm oak woodlands.

Author Contributions: Conceptualization: R.Q.C., A.C.-O., C.M.M., and C.P.G.; methodology: C.P.G. and S.d.R.; software: R.Q.C., J.C.P.F., and M.R.; validation: C.P.G. and S.d.R.; formal analysis: R.Q.C., 
A.C.-O., and C.M.M.; investigation: R.Q.C., A.C.-O., C.M.M., and J.C.P.F.; resources: R.Q.C., A.C.-O., C.M.M., and J.C.P.F.; data curation: R.Q.C., A.C.-O., C.M.M., and C.P.G.; writing-original draft preparation: R.Q.C.; writing-review and editing: C.P.G., A.C.-O., S.d.R., and C.M.M.; visualization: J.C.P.F.; supervision: C.P.G. and S.d.R. All authors have read and agreed to the published version of the manuscript.

Funding: This research received no external funding.

Acknowledgments: Diagram icons made by Freepik from https:/ /www.flaticon.com (accessed on 5 March 2021).

Conflicts of Interest: The authors declare no conflict of interest.

\section{Appendix A}

Table A1. Synoptic table of the holm oak woodlands linked to the Querco rotundifoliae-Oleenion sylvestris suballiance in the southwest of the Iberian Peninsula.

\begin{tabular}{|c|c|c|c|c|c|}
\hline Association no. & 1 & 2 & 3 & 4 & $\mathbf{P}$ \\
\hline \multicolumn{6}{|l|}{ Characteristic } \\
\hline Ulex argenteus & $\underline{\mathrm{V}}$ & - & - & - & 10 \\
\hline Scilla monophyllos & $\overline{\mathrm{IV}}$ & - & - & - & 5 \\
\hline Hyacinthoides hispanica & $\underline{\mathrm{II}}$ & - & - & - & 3 \\
\hline Luzula forsteri subsp. baeticum & $\overline{\mathrm{II}}$ & - & - & - & 3 \\
\hline Avenella stricta & $\underline{\underline{\mathrm{II}}}$ & - & - & - & 4 \\
\hline Carex hallerana & $\overline{\mathrm{I}}$ & - & - & - & 2 \\
\hline Senecio lopezii & \pm & - & - & - & 1 \\
\hline Phillyrea media & \pm & - & - & - & 1 \\
\hline Osyris lanceolata & \pm & - & - & - & 2 \\
\hline Erica arborea & $\underline{\bar{V}}$ & - & - & $\mathrm{I}$ & 11 \\
\hline Quercus rotundifolia & $\overline{\mathrm{V}}$ & $\mathrm{V}$ & 4 & $\mathrm{~V}$ & 28 \\
\hline Pistacia lentiscus & $\mathrm{V}$ & $\mathrm{V}$ & 2 & $\mathrm{~V}$ & 17 \\
\hline Rhamnus alaternus & IV & II & 2 & II & 13 \\
\hline Rubia peregrina & III & IV & 3 & IV & 13 \\
\hline Olea europaea var. sylvestris & III & II & 2 & $\mathrm{~V}$ & 17 \\
\hline Arbutus unedo & $\mathrm{V}$ & IV & - & IV & 20 \\
\hline Quercus coccifera & $\mathrm{V}$ & II & - & V & 21 \\
\hline Smilax aspera var. altissima & IV & III & 1 & - & 6 \\
\hline Phlomis purpurea & IV & I & 1 & - & 14 \\
\hline Phillyrea angustifolia & III & $\mathrm{V}$ & - & III & 10 \\
\hline Viburnum tinus & II & + & - & III & 5 \\
\hline Daphne gnidium & $\mathrm{I}$ & - & 1 & III & 17 \\
\hline Lonicera implexa & II & - & - & IV & 10 \\
\hline Ruscus aculeatus & II & - & - & III & 8 \\
\hline Asplenium onopteris & II & - & - & I & 3 \\
\hline Pyrus bourgaeana & + & $\mathrm{V}$ & - & I & 12 \\
\hline Rhamnus oleoides & + & - & 1 & III & 6 \\
\hline Myrtus communis & $\mathrm{I}$ & $\mathrm{V}$ & - & - & 12 \\
\hline Arum italicum subsp. neglectum & $\mathrm{I}$ & - & - & $\mathrm{I}$ & 2 \\
\hline Quercus suber & + & III & - & - & 7 \\
\hline Phillyrea latifolia & + & - & - & III & 3 \\
\hline $\begin{array}{l}\text { Arisarum vulgare subsp. } \\
\text { simorrhinum }\end{array}$ & + & - & - & II & 2 \\
\hline Elaeoselinum foetidum & + & - & - & II & 2 \\
\hline Vincetoxicum nigrum & - & $\underline{\text { III }}$ & - & - & 5 \\
\hline Moehringia pentandra & - & $\overline{ \pm}$ & - & - & 1 \\
\hline Asparagus acutifolius & - & $\overline{\mathrm{V}}$ & 1 & $\mathrm{~V}$ & 16 \\
\hline Anemone palmata & - & III & - & $\mathrm{I}$ & 6 \\
\hline Jasminum fruticans & - & II & - & $\mathrm{V}$ & 10 \\
\hline Osyris alba & - & II & - & III & 7 \\
\hline Chamaerops humilis & - & II & + & - & 4 \\
\hline Pistacia terebinthus & - & I & - & $\mathrm{V}$ & 9 \\
\hline Aristolochia baetica & - & - & $\underline{3}$ & - & 1 \\
\hline
\end{tabular}


Table A1. Cont.

\begin{tabular}{|c|c|c|c|c|c|}
\hline Association no. & 1 & 2 & 3 & 4 & $\mathbf{P}$ \\
\hline Ulex baeticus subsp. scaber & - & - & $\underline{1}$ & - & 1 \\
\hline Calicotome villosa & - & - & $\overline{1}$ & - & 1 \\
\hline Ceratonia siliqua & - & - & $\underline{1}$ & - & 1 \\
\hline Asparagus aphyllus & - & - & $\underline{1}$ & - & 1 \\
\hline Rosa sempervirens & - & - & \pm & - & 1 \\
\hline Clematis flammula & - & - & \pm & - & 1 \\
\hline Rhamnus laderoi & - & - & - & $\underline{\mathrm{V}}$ & $\underline{7}$ \\
\hline Teucrium fruticans & - & - & - & $\underline{\overline{\mathrm{III}}}$ & $\underline{\overline{4}}$ \\
\hline Smilax aspera var. aspera & - & - & - & III & $\underline{10}$ \\
\hline Thapsia nitida & - & - & - & $\underline{\underline{\text { III }}}$ & $\underline{3}$ \\
\hline Bupleurum fruticosum & - & - & - & $\underline{\text { III }}$ & $\underline{3}$ \\
\hline Paeonia broteroi & - & - & - & $\underline{I}$ & $\underline{2}$ \\
\hline Coronilla juncea & - & - & - & $\underline{\overline{I I}}$ & $\underline{2}$ \\
\hline Lonicera etrusca & - & - & - & $\overline{\overline{\mathrm{II}}}$ & $\underline{2}$ \\
\hline Asparagus albus & - & - & - & $\overline{\mathrm{I}}$ & $\underline{1}$ \\
\hline Coronilla glauca & - & - & - & $\overline{\mathrm{I}}$ & $\underline{1}$ \\
\hline $\begin{array}{l}\text { Juniperus oxycedrus subsp. } \\
\text { lagunae }\end{array}$ & - & - & - & $\underline{I}$ & $\underline{1}$ \\
\hline \multicolumn{6}{|l|}{ Companions } \\
\hline Sedum forsterianum & $\underline{\mathrm{V}}$ & - & - & - & 9 \\
\hline Lavandula viridis & $\underline{\bar{V}}$ & - & - & - & 8 \\
\hline $\begin{array}{l}\text { Dactylis hispanica subsp. } \\
\text { lusitanica }\end{array}$ & $\underline{\mathrm{V}}$ & - & - & - & 9 \\
\hline Picris spinifera & $\underline{\text { IV }}$ & - & - & - & 7 \\
\hline Thapsia villosa & $\overline{\mathrm{IV}}$ & - & - & - & 7 \\
\hline Rumex induratus & $\overline{\mathrm{IV}}$ & - & - & - & 6 \\
\hline Tamus communis & $\overline{\mathrm{IV}}$ & - & - & - & 5 \\
\hline Umbilicus rupestris & $\underline{\underline{\mathrm{III}}}$ & - & - & - & 6 \\
\hline $\begin{array}{l}\text { Arrhenatherum album var. } \\
\text { erianthum }\end{array}$ & $\underline{\text { III }}$ & - & - & - & 4 \\
\hline Lithodora lusitanica & $\underline{\text { III }}$ & - & - & - & 5 \\
\hline Phagnalon saxatile & $\underline{\underline{I I I}}$ & - & - & - & 5 \\
\hline Cynara algarbiensis & $\overline{\mathrm{II}}$ & - & - & - & 4 \\
\hline Asphodelus aestivus & $\underline{\mathrm{II}}$ & - & - & - & 6 \\
\hline Genista triacanthos & $\underline{\overline{I I}}$ & - & - & - & 4 \\
\hline Erophaca baetica & $\underline{\overline{I I}}$ & - & - & - & 3 \\
\hline Lavandula luisieri & $\underline{\overline{I I}}$ & - & - & - & 3 \\
\hline Digitalis purpurea & $\underline{\overline{I I}}$ & - & - & - & 3 \\
\hline Cistus populifolius & $\underline{\overline{I I}}$ & - & - & - & 2 \\
\hline Lavandula $x$ alportelensis & $\underline{\overline{I I}}$ & - & - & - & 2 \\
\hline Cistus $x$ hybridus & $\underline{\overline{I I}}$ & - & - & - & 2 \\
\hline $\begin{array}{l}\text { Anthyllis vulneraria subsp. } \\
\text { maura }\end{array}$ & $\underline{\text { II }}$ & - & - & - & 3 \\
\hline Sanguisorba rupicola & $\underline{\text { II }}$ & - & - & - & 4 \\
\hline Magydaris panacifolia & $\overline{\overline{I I}}$ & - & - & - & 3 \\
\hline Celtica gigantea & $\underline{\overline{I I}}$ & - & - & - & 2 \\
\hline Helichrysum stoechas & $\overline{\overline{I I}}$ & - & - & - & 2 \\
\hline Erica australis & $\underline{\overline{I I}}$ & - & - & - & 3 \\
\hline Geranium purpureum & $\overline{\mathrm{II}}$ & II & 1 & - & 8 \\
\hline Saxifraga granulata & II & $\mathrm{I}$ & - & - & 6 \\
\hline Brachypodium phoenicoides & II & $\mathrm{I}$ & - & - & 4 \\
\hline Cistus salviifolius & III & $\mathrm{V}$ & - & - & 16 \\
\hline Cistus ladanifer & III & III & - & - & 11 \\
\hline Pulicaria odora & $\mathrm{I}$ & III & - & - & 7 \\
\hline Aristolochia paucinervis & $\mathrm{I}$ & II & - & - & 3 \\
\hline Hymenocarpos lotoides & I & II & - & - & 3 \\
\hline Campanula rapunculus & + & II & - & - & 4 \\
\hline Cistus monspeliensis & - & $\underline{\mathrm{V}}$ & - & - & 9 \\
\hline
\end{tabular}


Table A1. Cont.

\begin{tabular}{|c|c|c|c|c|c|}
\hline Association no. & 1 & 2 & 3 & 4 & $\mathbf{P}$ \\
\hline Briza maxima & - & $\underline{\mathrm{V}}$ & - & - & 9 \\
\hline Agrostis castellana & - & $\underline{\bar{V}}$ & - & - & 8 \\
\hline Tuberaria guttata & - & $\underline{\bar{V}}$ & - & - & 9 \\
\hline Cistus crispus & - & $\underline{\bar{V}}$ & - & - & 9 \\
\hline Vulpia bromoides & - & $\underline{\bar{V}}$ & - & - & 9 \\
\hline Trifolium angustifolium & - & $\underline{\mathrm{IV}}$ & - & - & 7 \\
\hline Eryngium tenue & - & $\underline{\mathrm{IV}}$ & - & - & 8 \\
\hline Gastridium ventricosum & - & $\underline{\mathrm{IV}}$ & - & - & 7 \\
\hline Tolpis barbata & - & $\overline{\mathrm{IV}}$ & - & - & 7 \\
\hline Trifolium scabrum & - & $\underline{\mathrm{IV}}$ & - & - & 7 \\
\hline Cynosurus echinatus & - & $\overline{\mathrm{IV}}$ & - & - & 8 \\
\hline Brachypodium distachyon & - & $\underline{\mathrm{IV}}$ & - & - & 7 \\
\hline Rumex acetosella & - & $\underline{\mathrm{IV}}$ & - & - & 8 \\
\hline Trifolium glomeratum & - & $\underline{\mathrm{IV}}$ & - & - & 7 \\
\hline Bellis annua & - & $\underline{\mathrm{IV}}$ & - & - & 8 \\
\hline Lavandula stoechas & - & $\underline{\text { III }}$ & - & - & 6 \\
\hline Agrostis pourretii & - & $\underline{\overline{\mathrm{III}}}$ & - & - & 6 \\
\hline Calamintha nepeta & - & $\underline{\mathrm{III}}$ & - & - & 4 \\
\hline Cynara humilis & - & $\underline{\underline{\mathrm{III}}}$ & - & - & 6 \\
\hline Parentucellia viscosa & - & $\underline{\underline{\mathrm{III}}}$ & - & - & 5 \\
\hline Taeniatherum caput-medusae & - & $\overline{\mathrm{III}}$ & - & - & 6 \\
\hline Scilla autumnalis & - & $\underline{\underline{\mathrm{III}}}$ & - & - & 6 \\
\hline Leucojum autumnale & - & $\overline{\mathrm{III}}$ & - & - & 5 \\
\hline Aira cupaniana & - & $\underline{\underline{\mathrm{III}}}$ & - & - & 5 \\
\hline Aira caryophyllea & - & $\overline{\mathrm{III}}$ & - & - & 5 \\
\hline Molineriella minuta & - & $\underline{\underline{\mathrm{III}}}$ & - & - & 6 \\
\hline Dactylis glomerata & - & $\overline{\mathrm{III}}$ & - & - & 6 \\
\hline Teucrium haenseleri & - & $\underline{\underline{I I}}$ & - & - & 4 \\
\hline Cerastium brachypetalum & - & $\underline{\overline{I I}}$ & - & - & 4 \\
\hline Silene rubella subsp. segetalis & - & $\underline{\overline{I I}}$ & - & - & 3 \\
\hline Briza minor & - & $\overline{\mathrm{II}}$ & - & - & 2 \\
\hline Dittrichia viscosa & - & $\underline{\overline{I I}}$ & - & - & 3 \\
\hline Erica scoparia & - & $\underline{\overline{I I}}$ & - & - & 3 \\
\hline Thymus mastichina & - & $\underline{\overline{I I}}$ & - & - & 3 \\
\hline Ulex australis subsp. australis & - & $\underline{\overline{I I}}$ & - & - & 4 \\
\hline $\begin{array}{l}\text { Cytisus scoparius subsp. } \\
\text { scoparius }\end{array}$ & - & $\underline{\mathrm{II}}$ & - & - & 4 \\
\hline Margotia gummifera & - & $\underline{\text { II }}$ & - & - & 3 \\
\hline Lathyrus latifolius & - & $\underline{\overline{I I}}$ & - & - & 3 \\
\hline Coronilla dura & - & $\underline{\overline{I I}}$ & - & - & 4 \\
\hline Carlina racemosa & - & $\underline{\overline{I I}}$ & - & - & 4 \\
\hline Pulicaria paludosa & - & $\underline{\overline{I I}}$ & - & - & 4 \\
\hline Gaudinia fragilis & - & $\overline{\overline{I I}}$ & - & - & 3 \\
\hline Gladiolus reuteri & - & $\overline{\overline{I I}}$ & - & - & 4 \\
\hline Crataegus monogyna & - & $\overline{\mathrm{III}}$ & 2 & - & 7 \\
\hline Retama sphaerocarpa & - & III & + & - & 10 \\
\hline Cephalantera longifolia & - & II & - & II & 6 \\
\hline Melica ciliata subsp. magnolii & - & II & - & $\mathrm{I}$ & 5 \\
\hline Piptatherum miliaceum & - & - & $\underline{2}$ & - & 1 \\
\hline Cistus albidus & - & - & $\underline{1}$ & - & 1 \\
\hline Thymbra capitata & - & - & \pm & - & 1 \\
\hline Rubus ulmifolius & - & - & \pm & - & 1 \\
\hline Vinca difformis & - & - & \pm & - & 1 \\
\hline Ptilostemon hispanicus & - & - & $\underline{ \pm}$ & - & 1 \\
\hline Urginea maritima & - & - & - & $\underline{\text { II }}$ & $\underline{2}$ \\
\hline Cytisus striatus subsp. eriocarpus & - & - & - & $\underline{\overline{I I}}$ & $\underline{\underline{2}}$ \\
\hline Cytisus scoparius subsp. bourgaei & - & - & - & $\underline{I}$ & $\underline{1}$ \\
\hline
\end{tabular}


Table A1. Cont.

\begin{tabular}{llllll}
\hline Association no. & $\mathbf{1}$ & $\mathbf{2}$ & $\mathbf{3}$ & $\mathbf{4}$ & $\mathbf{P}$ \\
\hline Ballota hirsuta & - & - & - & $\underline{I}$ & $\underline{1}$ \\
Rosa pouzinii & - & - & - & $\underline{1}$ & $\underline{1}$ \\
Rosa canina & - & - & - & $\underline{1}$ & $\underline{1}$ \\
Nepeta tuberosa & - & - & - & $\underline{I}$ & $\underline{1}$ \\
\hline
\end{tabular}

Other taxa-Companions: Selaginella denticulata (P-2), Genista hirsuta (P-1), Clinopodium arundanum (P2), Lonicera periclymenum subsp. hispanica (P-1), Carlina corymbosa (P-1), Hyparrhenia sinaica (P-2) I in I, Arenaria montana (P-1), Senecio sylvaticus (P-1), Lupinus micranthus (P-1), Ranunculus paludosus (P-1), Allium massaesylum (P-1), Bellis sylvestris (P-1), Asplenium billotii (P-1), Allium roseum (P-1), Silene latifolia (P-1), Dianthus lusitanus (P-2), Ranunculus gramineus (P-1), Thymelaea villosa (P-2), Allium pallens (P-1), Campanula lusitanica (P-1), Anogramma leptophylla (P-1), Orchis morio (P-1) in I; Origanum virens (P-4), Fraxinus, angustifolia (P-2), Flueggea tinctoria (P-2), Scirpoides holoschoenus (P-2), Mentha suaveolens (P-2), Mentha pulegium (P-2), Halimium halimifolium (P-2), Calepina irregulares (P-2), Thapsia transtagana (P-2), Aristolochia pistolochia (P-2), Narcissus serotinus (P-2), Paronychia cymosa (P-2), Hymenocarpos cornicina (P-2), Ornithogalum broteroi (P-2) I in II; Salix atrocinerea (P-1), Nerium oleander (P-1), Juncus inflexus (P-1), Linum tenue (P-1), Trifolium resupinatum (P-1) + in II. P - frequency of total occurrence of the species in the dataset. Association: No. 1 Ulici argentei-Quercetum rotundifoliae (synthetic table from Appendix A, Table A3 of this paper, 10 relevés; clusters 1-10); No. 2 Myrto communis-Quercetum rotundifoliae Rivas Goday in Rivas Goday, Borja, Esteve, Galiano, Rigual \& Rivas-Martínez 1959 ([23]: Tab. 11, 10 relevés; clusters 11-20); No. 3-Rhamno oleoidis-Quercetum rotundifoliae Rivas-Martínez in Rivas-Martínez, Fernández-González, Loidi, Lousã \& Penas 2002 ([12]: 1 relevé, cluster 21); No. 4-Rhamno laderoi-Quercetum rotundifoliae Rivas-Martínez, M.T. Santos \& Ladero 2011 ([13]: 463, 7 relevés; clusters 22-28).

Table A2. Biogeographic, bioclimatic, substratum and floristic comparison between holm oak communities of the Southwestern Iberian Peninsula, included in the Querco rotundifoliae-Oleenion sylvestris suballiance.

\begin{tabular}{|c|c|c|c|c|}
\hline Holm Oak Association & $\begin{array}{c}\text { Biogeographic Units or } \\
\text { Territories }\end{array}$ & $\begin{array}{l}\text { Bioclimatic Units } \\
\text { (Thermotypes and } \\
\text { Ombrotypes) }\end{array}$ & $\begin{array}{l}\text { Substratum } \\
\text { Affinity }\end{array}$ & $\begin{array}{l}\text { Characteristics } \\
\text { and Main Differentials }\end{array}$ \\
\hline $\begin{array}{l}\text { Ulici argentei-Quercetum } \\
\text { rotundifoliae }\end{array}$ & $\begin{array}{c}\text { Monchique Sierran } \\
\text { District }\end{array}$ & $\begin{array}{c}\text { Thermomediterranean } \\
\text { sub-humid }\end{array}$ & $\begin{array}{l}\text { Silicicolous (schists and } \\
\text { greywackes substrates) }\end{array}$ & $\begin{array}{l}\text { Ulex argenteus, Scilla } \\
\text { monophyllos, Avenella } \\
\text { stricta, Lavandula viridis, } \\
\text { Cynara algarbiensis. }\end{array}$ \\
\hline $\begin{array}{c}\text { Myrto } \\
\text { communis-Quercetum } \\
\text { rotundifoliae }\end{array}$ & $\begin{array}{l}\text { Mediterranean- } \\
\text { Iberoatlantic }\end{array}$ & thermomediterranean dry & $\begin{array}{l}\text { Silicicolous (schists and } \\
\text { greywackes substrates) }\end{array}$ & $\begin{array}{l}\text { Myrtus communis, } \\
\text { Chamaerops humilis, } \\
\text { Lavandula sampaioana }\end{array}$ \\
\hline $\begin{array}{c}\text { Rhamno oleoidis-Quercetum } \\
\text { rotundifoliae }\end{array}$ & $\begin{array}{c}\text { Bética Province, reaching } \\
\text { the Algarve and } \\
\text { Monchique Sector, Cádiz } \\
\text { and Sado Subprovince }\end{array}$ & $\begin{array}{l}\text { thermomediterranean, dry } \\
\text { to subhumid }\end{array}$ & $\begin{array}{c}\text { Calcicolous (limestone } \\
\text { and calco-dolomitic } \\
\text { substrates) }\end{array}$ & $\begin{array}{c}\text { Ulex baeticus subsp. scaber, } \\
\text { Thymbra capitata, } \\
\text { Aristolochia baetica, } \\
\text { Ptilostemon hispanicus }\end{array}$ \\
\hline $\begin{array}{c}\text { Rhamno laderoi-Quercetum } \\
\text { rotundifoliae }\end{array}$ & $\begin{array}{l}\text { Lusitania and } \\
\text { Extremadura Subprovince }\end{array}$ & $\begin{array}{c}\text { upper } \\
\text { thermomediterranean or } \\
\text { lower mesomediterranean, } \\
\text { subhumid }\end{array}$ & $\begin{array}{l}\text { Calcicolous (calcareous, } \\
\text { calco-dolomitic and } \\
\text { ultramafic or serpentine } \\
\text { substrates) }\end{array}$ & $\begin{array}{l}\text { Rhamnus lycioides subsp. } \\
\text { laderoi, Teucrium fruticans }\end{array}$ \\
\hline
\end{tabular}

Table A3. Ulici argentei-Quercetum rotundifoliae ass. nova hoc loco (Querco rotundifoliae-Oleenion sylvestris, Oleo sylvestris-Quercion rotundifoliae, Quercetalia ilicis, Quercetea ilicis).

\begin{tabular}{|c|c|c|c|c|c|c|c|c|c|c|c|}
\hline Relevé no. & 1 & 2 & 3 & 4 & 5 & 6 & $7 *$ & 8 & 9 & 10 & \\
\hline Surface $\left(\mathrm{m}^{2}\right)$ & 200 & 250 & 150 & 400 & 300 & 200 & 300 & 150 & 150 & 150 & \\
\hline Altitude (m) & 170 & 135 & 155 & 165 & 260 & 165 & 160 & 390 & 375 & 385 & PRESENCES \\
\hline Cover rate $(\%)$ & 90 & 80 & 70 & 85 & 95 & 80 & 100 & 90 & 95 & 70 & \\
\hline Orientation & $\mathbf{O}$ & SE & SE & $\mathbf{O}$ & NE & NE & $\mathbf{O}$ & SE & NE & SE & \\
\hline Slope $(\%)$ & 35 & 20 & 25 & 25 & 30 & 20 & 30 & 10 & 30 & 5 & \\
\hline Altura média (m) & 6 & 6 & 5 & 5 & 8 & 6 & 8 & 4 & 7 & 3 & \\
\hline No. of species & 30 & 27 & 32 & 39 & 19 & 38 & 35 & 35 & 24 & 15 & \\
\hline \multicolumn{12}{|c|}{ Characteristic of association and higher units } \\
\hline Quercus rotundifolia & 5 & 4 & 3 & 4 & 5 & 4 & 5 & 4 & 4 & 3 & $\mathbf{V}$ \\
\hline Erica arborea & 1 & 2 & 2 & 1 & + & + & 1 & + & 2 & + & $\mathbf{V}$ \\
\hline
\end{tabular}


Table A3. Cont.

\begin{tabular}{|c|c|c|c|c|c|c|c|c|c|c|c|}
\hline Relevé no. & 1 & 2 & 3 & 4 & 5 & 6 & $7 *$ & 8 & 9 & 10 & \multirow{8}{*}{ PRESENCES } \\
\hline Surface $\left(\mathrm{m}^{2}\right)$ & 200 & 250 & 150 & 400 & 300 & 200 & 300 & 150 & 150 & 150 & \\
\hline Altitude (m) & 170 & 135 & 155 & 165 & 260 & 165 & 160 & 390 & 375 & 385 & \\
\hline Cover rate (\%) & 90 & 80 & 70 & 85 & 95 & 80 & 100 & 90 & 95 & 70 & \\
\hline Orientation & $\mathrm{O}$ & SE & $\mathrm{SE}$ & $\mathrm{O}$ & $\mathrm{NE}$ & $\mathrm{NE}$ & $\mathrm{O}$ & SE & $\mathrm{NE}$ & SE & \\
\hline Slope (\%) & 35 & 20 & 25 & 25 & 30 & 20 & 30 & 10 & 30 & 5 & \\
\hline Altura média (m) & 6 & 6 & 5 & 5 & 8 & 6 & 8 & 4 & 7 & 3 & \\
\hline No. of species & 30 & 27 & 32 & 39 & 19 & 38 & 35 & 35 & 24 & 15 & \\
\hline Quercus coccifera & + & + & 1 & 1 & 2 & 1 & 1 & + & + & 1 & $\mathbf{V}$ \\
\hline Ulex argenteus & 1 & + & 2 & 2 & - & 1 & + & 1 & + & 2 & $\mathbf{V}$ \\
\hline Pistacia lentiscus & + & 1 & 2 & + & - & 1 & + & + & 1 & + & $\mathbf{V}$ \\
\hline Arbutus unedo & 1 & + & 1 & 1 & 1 & - & 1 & 1 & - & 1 & IV \\
\hline Phlomis purpurea & - & 1 & 1 & 1 & - & + & + & 1 & - & + & IV \\
\hline Rhamnus alaternus & + & 1 & 1 & - & - & 1 & + & - & + & - & III \\
\hline $\begin{array}{l}\text { Smilax aspera var. } \\
\text { altissima }\end{array}$ & 1 & 1 & 1 & - & 1 & + & 2 & - & - & - & III \\
\hline Phillyrea angustifolia & 1 & - & - & + & - & - & 1 & 2 & - & 1 & III \\
\hline $\begin{array}{l}\text { Olea europaea var. } \\
\text { sylvestris }\end{array}$ & - & + & + & + & - & + & - & + & - & - & III \\
\hline Scilla monophyllos & 1 & 1 & + & - & + & - & 2 & - & - & - & III \\
\hline Rubia peregrina & + & + & - & - & 1 & - & 1 & - & - & - & II \\
\hline Lonicera implexa & - & - & + & + & - & - & + & + & - & - & II \\
\hline Avenella stricta & - & - & - & + & + & - & + & + & - & - & II \\
\hline Ruscus aculeatus & - & - & - & + & - & 1 & + & - & + & - & II \\
\hline $\begin{array}{l}\text { Hyacinthoides } \\
\text { hispanica }\end{array}$ & - & - & - & - & 1 & + & - & - & + & - & II \\
\hline $\begin{array}{l}\text { Luzula forsteri } \\
\text { subsp. baeticum }\end{array}$ & - & - & - & - & + & + & + & - & - & - & II \\
\hline Asplenium onopteris & - & - & - & - & - & 2 & - & - & + & - & I \\
\hline Daphne gnidium & - & - & + & - & - & - & - & + & - & - & I \\
\hline Osyris lanceolata & - & - & - & - & - & - & - & + & - & + & I \\
\hline Myrtus communis & - & - & - & + & - & - & - & - & + & - & I \\
\hline Carex hallerana & - & - & - & + & - & + & - & - & - & - & $\mathbf{I}$ \\
\hline \multicolumn{12}{|l|}{ Companions } \\
\hline $\begin{array}{l}\text { Dactylis hispanica } \\
\text { subsp. Iusitanica }\end{array}$ & + & + & + & 1 & - & 1 & + & + & + & + & $\mathbf{V}$ \\
\hline Sedum forsterianum & + & 1 & 1 & 1 & - & 1 & + & + & + & - & IV \\
\hline Lavandula viridis & 1 & 1 & - & + & + & 1 & + & + & 2 & - & IV \\
\hline Picris spinifera & - & 1 & 1 & 1 & + & + & + & + & - & - & IV \\
\hline Cistus salviifolius & + & + & + & + & - & - & - & + & + & + & IV \\
\hline Thapsia villosa & + & + & + & 1 & - & 1 & + & - & 2 & - & IV \\
\hline Umbilicus rupestris & - & - & - & + & + & - & + & + & + & + & III \\
\hline Phagnalon saxatile & + & + & + & + & - & - & - & - & + & - & III \\
\hline Rumex induratus & + & + & + & + & - & + & + & - & - & - & III \\
\hline Tamus communis & 1 & + & - & - & 2 & 2 & - & - & 1 & - & III \\
\hline Lithodora lusitanica & - & + & + & + & - & - & + & + & - & - & III \\
\hline $\begin{array}{l}\text { Cistus ladanifer } \\
\text { Arrhenatherum }\end{array}$ & + & - & + & 1 & - & + & - & - & - & + & III \\
\hline $\begin{array}{l}\text { album var. } \\
\text { erianthum }\end{array}$ & - & - & + & + & - & + & - & + & - & - & II \\
\hline Cynara algarbiensis & + & - & 1 & - & - & + & + & - & - & - & II \\
\hline Saxifraga granulata & - & - & - & - & + & 1 & + & - & + & - & II \\
\hline Genista triacanthos & - & + & - & 1 & - & + & - & + & - & - & II \\
\hline Sanguisorba rupicola & + & + & - & + & - & - & + & - & - & - & II \\
\hline Erica australis & + & - & - & 1 & - & - & - & + & - & - & II \\
\hline $\begin{array}{l}\text { Geranium } \\
\text { purpureum }\end{array}$ & + & - & - & - & + & 1 & + & - & - & - & II \\
\hline $\begin{array}{l}\text { Brachypodium } \\
\text { phoenicoides }\end{array}$ & + & - & + & - & - & + & - & - & - & - & II \\
\hline Erophaca baetica & + & - & - & - & - & + & - & + & - & - & II \\
\hline Lavandula luisieri & - & - & 1 & - & - & - & - & 1 & + & - & II \\
\hline Digitalis purpurea & + & - & - & - & - & + & + & - & - & - & II \\
\hline $\begin{array}{l}\text { Anthyllis vulneraria } \\
\text { subsp. maura }\end{array}$ & - & - & - & + & - & + & + & - & - & - & II \\
\hline
\end{tabular}


Table A3. Cont.

\begin{tabular}{|c|c|c|c|c|c|c|c|c|c|c|c|}
\hline Relevé no. & 1 & 2 & 3 & 4 & 5 & 6 & $7 *$ & 8 & 9 & 10 & \multirow{8}{*}{ PRESENCES } \\
\hline Surface $\left(\mathrm{m}^{2}\right)$ & 200 & 250 & 150 & 400 & 300 & 200 & 300 & 150 & 150 & 150 & \\
\hline Altitude (m) & 170 & 135 & 155 & 165 & 260 & 165 & 160 & 390 & 375 & 385 & \\
\hline Cover rate (\%) & 90 & 80 & 70 & 85 & 95 & 80 & 100 & 90 & 95 & 70 & \\
\hline Orientation & $\mathrm{O}$ & SE & SE & $\mathrm{O}$ & NE & NE & $\mathbf{O}$ & SE & NE & SE & \\
\hline Slope (\%) & 35 & 20 & 25 & 25 & 30 & 20 & 30 & 10 & 30 & 5 & \\
\hline Altura média (m) & 6 & 6 & 5 & 5 & 8 & 6 & 8 & 4 & 7 & 3 & \\
\hline No. of species & 30 & 27 & 32 & 39 & 19 & 38 & 35 & 35 & 24 & 15 & \\
\hline $\begin{array}{l}\text { Magydaris } \\
\text { panacifolia }\end{array}$ & - & + & - & + & - & - & + & - & - & - & II \\
\hline Genista hirsuta & - & - & - & - & - & - & - & 1 & + & + & II \\
\hline Cistus populifolius & + & - & - & - & - & - & + & - & - & - & $\mathbf{I}$ \\
\hline $\begin{array}{l}\text { Lavandula } \mathrm{x} \\
\text { alportelensis }\end{array}$ & - & - & - & 1 & - & - & - & 2 & - & - & I \\
\hline Cistus $\mathrm{x}$ hybridus & - & + & + & - & - & - & - & - & - & - & I \\
\hline Celtica gigantea & - & - & - & + & - & + & - & - & - & - & I \\
\hline $\begin{array}{l}\text { Helichrysum } \\
\text { stoechas }\end{array}$ & - & - & - & + & - & - & - & + & - & - & $\mathbf{I}$ \\
\hline $\begin{array}{l}\text { Selaginella } \\
\text { denticulata }\end{array}$ & - & - & - & - & + & - & - & - & + & - & I \\
\hline Thymelaea villosa & - & - & - & - & - & - & - & + & - & + & I \\
\hline $\begin{array}{l}\text { Clinopodium vulgare } \\
\text { subsp. arundanum }\end{array}$ & - & - & - & - & + & + & - & - & - & - & I \\
\hline Pulicaria odora & + & - & - & + & - & - & - & - & - & - & I \\
\hline Carlina corymbosa & - & + & - & - & - & - & - & - & - & - & I \\
\hline Hyparrhenia sinaica & - & - & - & + & - & - & - & + & - & - & $\mathbf{I}$ \\
\hline
\end{tabular}

Other taxa-Characteristic: + Senecio lopezii in 3; + Pyrus bourgaeana in 6; 2 Arum italicum subsp. neglectum in 7; + Quercus suber, + Rhamnus oleoides in 8; Companions: + Senecio sylvaticus in 1; + Urginea maritima, + Lupinus micranthus, + Ranunculus paludosus in 3; + Campanula rapunculus, + Arenaria montana in 4; + Asplenium billotii in 5; + Allium roseum, 1 Silene latifolia, r Dianthus lusitanus; $\mathrm{r}$ Ranunculus gramineus in 6; + Allium massaesylum, + Bellis sylvestris in 7; + Cheilanthes guanchica, + Allium pallens, + Campanula lusitanica in 8; + Anogramma leptophylla, + Orchis morio in 9. Location of the relevés: 1-Monte Novo da Eirinha (near Azilheira); 2-Cerro da Fonte (near S. Marcos da Serra); 3-Corte Peral; 4-Carrapareira; 5-Casinha; 6-Aziheira; 7 ( ${ }^{*}$ holotypus)-Boi (near Rib. ${ }^{a}$ de Odelouca); 8-Negro; 9-Barranco da Muda (near Cova da Muda); 10-Negro.

\section{References}

1. Martínez, S.R. Mapa de Series, Geoseries y Geopermaseries de Vegetación de España (Memoria Del Mapa de Vegetación Potencial de España). Parte 1. Itinera Geobot. 2007, 17, 5-436.

2. Rivas-Martínez, S.; Penas, Á.; Díaz González, T.E.; Cantó, P.; del Río, S.; Costa, J.C.; Herrero, L.; Molero, J. Biogeographic Units of the Iberian Peninsula and Baelaric Islands to District Level. A Concise Synopsis. In The Vegetation of the Iberian Peninsula; Loidi, J., Ed.; Plant and Vegetation; Springer International Publishing: Cham, Switzerland, 2017; Volume 1, pp. 131-188. ISBN 978-3-319-54784-8.

3. Loidi, J. Dynamism in Vegetation. Vegetation Changes on a Short Time Scale. In The Vegetation of the Iberian Peninsula; Springer: Cham, Switzerland, 2017; pp. 81-99. [CrossRef]

4. Piñar Fuentes, J.C.; Cano-Ortiz, A.; Musarella, C.M.; Pinto-Gomes, C.; Spampinato, G.; Cano, E. Rupicolous habitats of interest for conservation in the central-southern Iberian Peninsula. Plant Sociol. 2017, 54, 29-42. [CrossRef]

5. Piñar Fuentes, J.C.; Cano-Ortiz, A.; Musarella, C.M.; Quinto Canas, R.; Pinto Gomes, C.J.; Spampinato, G.; del Río, S.; Cano, E. Bioclimatology, Structure, and Conservation Perspectives of Quercus Pyrenaica, Acer opalus subsp. granatensis, and Corylus avellana Deciduous Forests on Mediterranean Bioclimate in the South-Central Part of the Iberian Peninsula. Sustainability 2019, 11, 6500. [CrossRef]

6. Braun-Blanquet, J. Vegetationsskizzen Aus Dem Baskenland Mit Ausblicken Auf Das Weitere Ibero-Atlantikum II Teil. Vegetatio 1967, 14, 1-126. [CrossRef]

7. Géhu, J.M.; Rivas-Martínez, S. Notions Fondadamentales de Phytosociologie. In Berichte der internationalen Symposien. Syntaxonomie IV-V Int. Vaduz; Dierschke, H., Ed.; Rinteln, Germany, 1981; pp. 5-33.

8. Rivas-Martínez, S. Avances En Geobotánica. In Discurso de Apertura Del Curso Académico de La Real Academia Nacional de Farmacia Del Año 2005; Real Acad. Nacional de Farmacia: Madrid, Spain, 2005.

9. Biondi, E. Phytosociology Today: Methodological and Conceptual Evolution. Plant Biosyst.-Int. J. Deal. All Asp. Plant Biol. 2011, 145, 19-29. [CrossRef]

10. Braun-Blanquet, J. Fitosociología. Bases Para El Estudio de Las Comunidades Vegetales; H. Blume: Madrid, Spain, 1979. 
11. Rivas-Martínez, S.; Fernández-González, F.; Loidi, J.; Lousã, M.; Penas, Á. Syntaxonomical Checklist of Vascular Plant Communities of Spain and Portugal to Association Level. Itinera Geobot. 2001, 14, 5-341.

12. Rivas-Martínez, S.; Díaz, T.E.; Fernández-González, F.; Izco, J.; Loidi, J.; Lousã, M.; Penas, Á. Vascular Plant Communities of Spain and Portugal: Addenda to the Syntaxonomical Checklist of 2001. Itinera Geobot. 2002, 15, 5-922.

13. Rivas Martínez, S.; Penas, Á.; Díaz González, T.E.; Ladero, M.; Asensi, A.; Díez Garretas, B.; Molero Mesa, J.; Valle Tendero, F.; Cano, E.; Costa Talens, M.; et al. Mapa de series, geoseries y geopermaseries de vegetación de España (Memoria del mapa de vegetación potencial de España). Parte II. Itinera Geobot. 2011, 18, 5-800.

14. Costa, J.C.; Neto, C.; Aguiar, C.; Capelo, J.; Espírito-Santo, M.D.; Honrado, J.; Pinto-Gomes, C.; Monteiro-Henriques, T.; Sequeira, M.; Lousã, M. Vascular Plant Communities in Portugal (Continental, Azores and Madeira). Glob. Geobot. 2012, 2, 1-180.

15. Mucina, L.; Bültmann, H.; Dierßen, K.; Theurillat, J.-P.; Raus, T.; Čarni, A.; Šumberová, K.; Willner, W.; Dengler, J.; García, R.G.; et al. Vegetation of Europe: Hierarchical floristic classification system of vascular plant, bryophyte, lichen, and algal communities. Appl. Veg. Sci. 2016, 19, 3-264. [CrossRef]

16. Coutinho, A. Flora de Portugal (Plantas Vasculares), 2nd ed.; Bertrand: Lisboa, Portugal, 1939.

17. Franco, J. Nova Flora de Portugal (Continente e Açores); Escolar: Lisboa, Portugal, 1971; Volume I.

18. Franco, J.; Rocha-Afonso, M. Nova Flora de Portugal (Continente e Açores); Escolar: Lisboa, Portugal, 1994; Volume III.

19. Castroviejo, S. Flora Iberica; Real Jardín Botánico; CSIC: Madrid, Spain, 1986.

20. Valdés, B.; Talavera, S.; Fernández-Galiano, E. Flora Vascular de Andalucía Occidental; Ketres: Barcelona, Spain, 1987.

21. Sequeira, M.; Espírito-Santo, D.; Aguiar, C.; Capelo, C.; Honrado, J.J. (Eds.) Checklist da Flora de Portugal Continental, Açores e Madeira; ALFA: Lisboa, Portugal, 2011.

22. Rivas-Martínez, S.; Penas, Á.; del Río, S.; Díaz González, T.E.; Rivas-Sáenz, S. Bioclimatology of the Iberian Peninsula and the Balearic Islands. In The Vegetation of the Iberian Peninsula; Loidi, J., Ed.; Plant and Vegetation; Springer International Publishing: Cham, Switzerland, 2017; Volume 1, pp. 29-80. ISBN 978-3-319-54784-8.

23. Rivas Goday, S.; Borja, J.; Esteve, F.; Galiano, E.F.; Rigual, A.; Rivas-Martínez, S. Contribución al Estudio de La Quercetea Ilicis Hispánica. An. Inst. Bot. Cavanilles 1959, 285-406.

24. Quinto-Canas, R. Flora y Vegetación de La Serra Do Caldeirão. Ph.D. Thesis, Facultad Ciencias Experimentales, Universidad de Jaén, Jaén, Spain, 2014.

25. Theurillat, J.P.; Willner, W.; Fernández-González, F.; Bültmann, H.; Čarni, A.; Gigante, D.; Mucina, L.; Weber, H. International Code of Phytosociological Nomenclature. 4th edition. Appl. Veg. Sci. 2020, 1-62. [CrossRef]

26. Clarke, K.R. Non-Parametric Multivariate Analyses of Changes in Community Structure. Aust. J. Ecol. 1993, 18, 117-143. [CrossRef]

27. Clarke, K.R.; Gorley, R.N. Primer v6 User Manual/Tutorial: Software for PRIMER-E (Version 6.1.5); PRIMER-E: Plymouth, UK, 2006.

28. Van der Maarel, E. Transformation of Cover Abundance Values in Phytosociology and Its Effects on Community Similarity. Vegetation 1979, 97-114. [CrossRef]

29. Quinto-Canas, R.; Mendes, P.; Meireles, C.; Musarella, C.; Pinto-Gomes, C. The Agrostion castellanae Rivas Goday 1957 Corr. Rivas Goday \& Rivas- Martínez 1963 Alliance in the Southwestern Iberian Peninsula. Plant Sociol. 2018, 55, 21-29. [CrossRef]

30. Paiva-Ferreira, R.; Pinto-Gomes, C. Flora e Vegetação do Barrocal Algarvio, Tavira-Portimão; Comissão de Coordenação e Desenvolvimento Regional do Algarve: Faro, Portugal, 2005.

31. Molero, J.; Marfil, J.M. Betic and Southwest Andalusia. In The Vegetation of the Iberian Peninsula; Loidi, J., Ed.; Plant and Vegetation; Springer International Publishing: Cham, Switzerland, 2017; Volume 2, pp. 143-247. ISBN 978-3-319-54867-8.

32. Quinto-Canas, R.; Vila-Viçosa, C.; Paiva-Ferreira, R.; Cano-Ortiz, A.; Pinto-Gomes, C. The Algarve Climatophilous Vegetation -Portugal: A Base Document to the Planning, Management and Nature Conservation. Acta Bot. Gall. 2012, 159, 289-298. [CrossRef]

33. Aubard, V.; Paulo, J.A.; Silva, J.M.N. Long-Term Monitoring of Cork and Holm Oak Stands Productivity in Portugal with Landsat Imagery. Remote Sens. 2019, 11, 525. [CrossRef] 